\title{
Population, Population Density, AND TECHNOLOGICAL CHANGE
}

\author{
STEPHAN KLASEN \\ THORSTEN NESTMANN
}

\author{
CESIFO WORKING PAPER NO. 1209 \\ CATEGORY 10: EMPIRICAL AND THEORETICAL METHOdS \\ JUNE 2004
}
An electronic version of the paper may be downloaded
- from the SSRN website:
www.SSRN.com
- from the CESifo website:
www.CESifo.de




\title{
Population, Population Density, AND TECHNOLOGICAL CHANGE
}

\begin{abstract}
In a model on population and endogenous technological change, Kremer combines a short-run Malthusian scenario where income determines the population that can be sustained, with the Boserupian insight that greater population spurs technological change and can therefore lift a country out of its Malthusian trap. We show that a more realistic version of the model, which combines population and population density, allows deeper insights into these processes. The incorporation of population density also allows a superior interpretation of the empirical regularities between the level of population, population density, population growth, and economic development, both at aggregated and disaggregated levels.
\end{abstract}

JEL classification: O3, J1, N3.

\author{
Stephan Klasen \\ Department of Economics \\ University of Goettingen \\ Platz der Göttinger Sieben 3 \\ 37073 Göttingen \\ Germany \\ sklasen@uni-goettingen.de
}

\author{
Thorsten Nestmann \\ Department of Economics \\ University of Mainz \\ Jakob-Welder-Weg 4 \\ 55099 Mainz \\ Germany \\ Nestmann@uni-mainz.de
}

We would like to thank Michael Kremer, participants at a research seminar at the University of Munich as well as at participants of a session at the 2001 EEA conference in Lausanne for helpful comments and suggestions. 


\section{Introduction}

Economic views on the impact of population have been dominated by two paradigms. In the Malthusian paradigm, population growth that exceeds technological change ensures that societies are never able to escape subsistence levels of income. In the Boserupian paradigm which is also found in some versions of endogenous growth models, the level of population determines the pace of technological change and thus can help countries escape the Malthusian trap.

In a well-known article published in 1993, Michael Kremer combines these two paradigms to analyse the relationship between global population and population growth over the past one million years. In particular, he combines a Malthusian equation where a given income level determines the population that can be sustained, with a technological change equation which posits that the level of population positively influences technological change, can thus lift the income constraint, and consequently allow population growth to take place. This model predicts a linear relationship between the growth rate of population and its absolute level, and he shows that this highly stylised model can describe the empirical relationship between these two variables from earliest times up to about 1960 surprisingly well.

In various extensions to the model, Kremer addresses some of the unrealistic features of this basic formulation. These extensions allow for some populous countries having rather low technological levels, for roughly constant technological change, for falling global population growth rates after 1960, and for rising per capita incomes, all of which are features of the contemporary world.

In Kremer's framework, technological change is dependent on the absolute level of population and, in the extensions, additionally on the level of income and technology. We argue that it is more plausible to assume that technological change depends additionally on population density, as population density facilitates communication and exchange, increases the size of markets and the scope for specialisation, and creates the required demand for innovation, all of which should spur the creation and diffusion of new technologies (see also Becker et al. 1999).

Within the general framework of Kremer's model, we then extend the model by including population density as an additional factor influencing technological change. This extension not only is able to still explain all of the empirical regularities noted by Kremer, but does so more plausibly and generates additional insights into the interactions between population and technological change. It also provides a better explanation of differences in technological levels between geographically separated regions and has more plausible policy implications. Lastly, data at a more disaggregated 
country or regional level show a clear correlation between population density and subsequent levels of per capita GDP, which cannot be easily accommodated in Kremer's original model but is consistent with our extension that includes population density.

The paper is structured as follows. First, the simple version and the most important extension of the Kremer model is presented. Then we incorporate our extension, the additional consideration of population density in a generalised version of the model. New insights will be highlighted and interpreted and implications for current research in development economics emphasised.

\section{The basic model}

Kremer's simple version of the model is based on two fundamental assumptions: The first stems from the idea that technology is a public good because it has the property of non-rivalry, and, as Romer (1990) points out, blueprints are -at least as an input for further research activities- non-excludable. In this simple version, Kremer also assumes that each person's research productivity is independent of population size. As a result, there are more inventors in larger populations. Combined with the public good character of technology, larger populations therefore exhibit higher growth rates of technology.

The second assumption is related to Thomas Malthus' famous 1798 essay on population. He observed that population grows geometrically whereas food production increases only arithmetically. Through a process of alternating subsistence crises, where famine kills a large share of the population, and subsequent phases of expanding population, population and food production are held in balance. The growth rate of population is thus limited by the state of food production, i.e. technological progress ${ }^{1}$.

Combining the hypothesis that high population spurs technological change with the Malthusian view that technology determines population leads to the prediction that the growth rate of population is proportional to the size of population. Kremer finds empirical evidence for this prediction over most of human history.

\footnotetext{
${ }^{1}$ According to Galor and Weil (1999), most of human history was characterised by this "Malthusian Regime". Only in the last 200 years, humans were able to leave the subsistence level and to create and accumulate wealth.
} 
Formally, output (Y) is generated in a Cobb-Douglas type production process. Land (T) and population $(\mathrm{P})$ are used as inputs. The output level also depends on the current state of technology $(\mathrm{A})^{2}$

(1) $\mathrm{Y}=\mathrm{A} * \mathrm{P}^{\alpha} * \mathrm{~T}^{(1-\alpha)}, \quad \alpha>0$

After normalising $\mathrm{T}$ to one and dividing both sides by $\mathrm{P}$, we obtain output per capita (y) as:

(1a) $\quad \mathrm{y}=\mathrm{A} * \mathrm{P}^{(\alpha-1)}$

According to Malthus (1798), income per capita cannot exceed the subsistence level. In the case of good economic conditions, mortality would fall and more children would be born. An increase in output would therefore not lead to a rise in output per capita but to an increase in the size of the population. In this version of the model, Kremer assumes that this process of population adjusting to economic conditions occurs instantaneously. Per capita income can therefore be assumed as constant, implied by $\bar{y}$.

Equation (1a) can be solved for the equilibrium level of the population size P.

(2) $\mathrm{P}=\left(\frac{\overline{\mathrm{y}}}{\mathrm{A}}\right)^{(1 / \alpha-1)}$

The following research equation (3) shows, that the chance to invent something new is dependent of population size, with each person having the same research productivity. The larger the level of population, the higher will thus be the growth rate of technology.

(3) $\frac{\dot{\mathrm{A}}}{\mathrm{A}}=\mathrm{P}^{*} \mathrm{~g}$

with $\dot{A}$ / $A$ representing the growth rate of technology and g standing for research productivity per person.

In the next step we determine the growth rate of population. By assumption, the level of per capita income is constant, so its growth rate is equal to zero $(\mathrm{dlny}(\mathrm{t}) / \mathrm{dt}=0)$. Taking logarithms in (2) leads to

(2a) $\ln (\mathrm{P})=\frac{1}{1-\alpha}(\ln (\mathrm{y})-\ln (\mathrm{A}))$

\footnotetext{
${ }^{2}$ Introducing capital in the production does not lead to further insights. For details, see Kremer (1993).
} 
The growth rates are obtained by differentiating this term with respect to time. This leads to equation (4).

$$
\frac{\dot{\mathrm{P}}}{\mathrm{P}}=\frac{1}{1-\alpha} * \frac{\dot{\mathrm{A}}}{\mathrm{A}}
$$

Substituting $\dot{A} / A$ from equation (3) in (4) shows the relationship between the growth rate of population and its size in (5).

$$
\frac{\dot{\mathrm{P}}}{\mathrm{P}}=\frac{\mathrm{g}}{1-\alpha} * \mathrm{P}
$$

This relationship between the growth rate of population and its size is shown in Figure 1. On the horizontal axis we plot the size of the world population for 1.000 .000 B.C. until 1997. The vertical axis shows the corresponding average annual growth rate of the world's population in percent. Until about 1960 (when world population was about 3 billion), there appears to be a linear relationship between the two variables. ${ }^{3}$ After 1960 when world population had reached about 3 billion people, populations growth stabilised and then fell. ${ }^{4}$

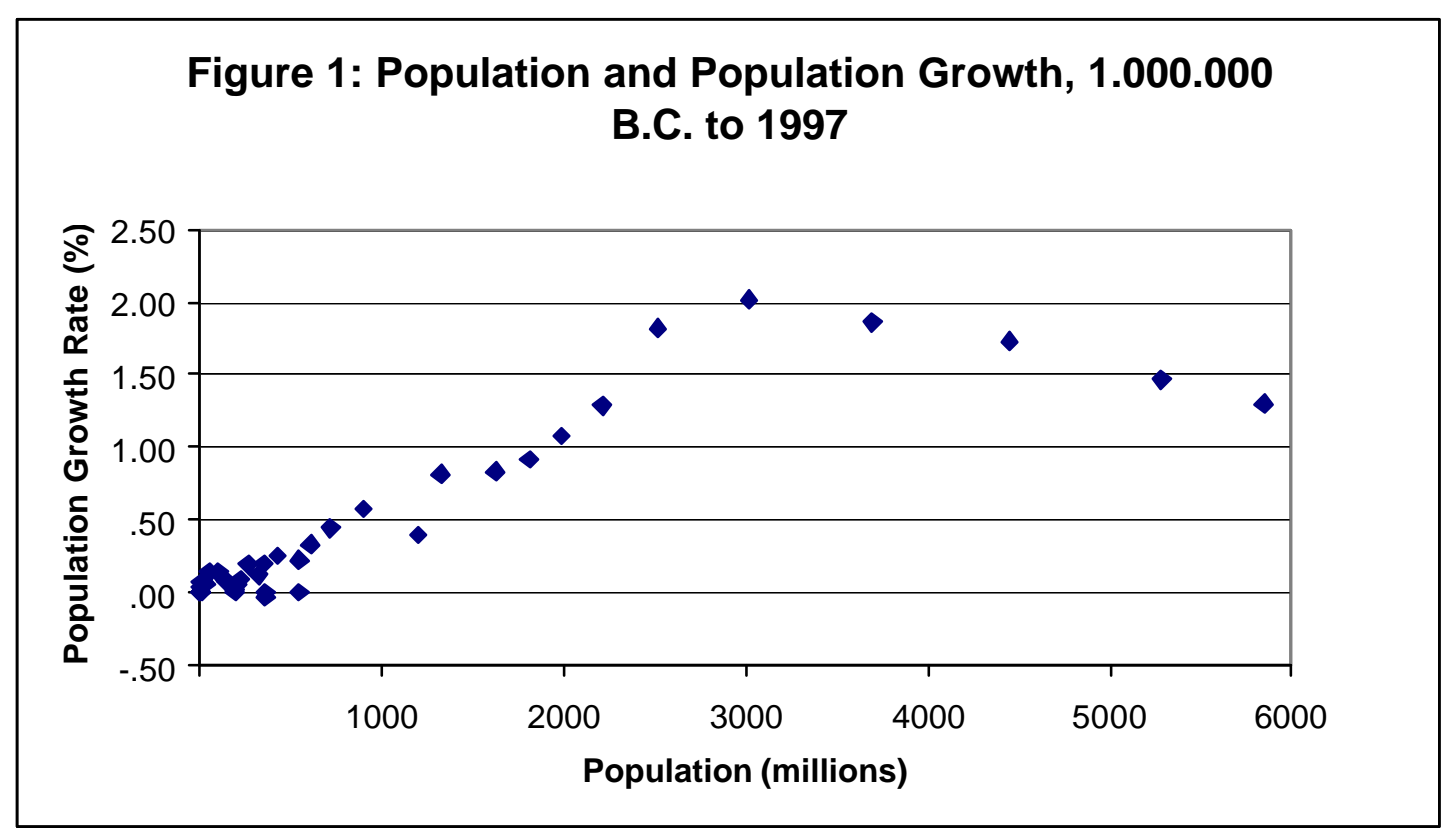

Source: Kremer (1993) and UN (1998).

\footnotetext{
${ }^{3}$ There are a few outliers in the middle ages where population growth rates were in three instances lower than one would have expected. They are associated with the demographic impact of the Mongol invasions in the $13^{\text {th }}$ century, the black death in the $14^{\text {th }}$ century, and the 30 -years war and the fall of the Ming Dynasty in the $17^{\text {th }}$ century.

${ }^{4}$ Kremer accommodates this period in one of his extensions of the model (see below).
} 
This version of the model is based on very restrictive assumptions. Therefore, Kremer (1993) relaxes some of them in more generalised versions of the model. First, he takes into account that research productivity (g) may depend on income, i.e. be a function of income. In particular, higher incomes may increase the research productivity per person. With this extension, it is possible to explain why some populous countries like China or India have comparatively low technological levels. Secondly, he takes the view of Jones $(1992,1995)$ that it is arbitrary to assume a linear relationship between the growth rate of technology and its level. Assuming an exponent of less than one for the technological level (A) in equation (3) is in line with a constant or declining total factor productivity in the post-war period. Thirdly, he relaxes the assumption that research productivity is independent of the size of the population. He formulates a research equation (3) which also contains an exponent attched to $\mathrm{P}$, the population level. This is due to the fact that research productivity may increase with population as suggested by Kuznets (1960), Grossman and Helpman (1991) or Aghion and Howitt (1992). Alternatively, at some level, research productivity may also decrease with population size because of redundant research activities.

Thus the more general technological change equation becomes ${ }^{5}$ :

(3a) $\frac{\dot{\mathrm{A}}}{\mathrm{A}}=\mathrm{g} * \mathrm{P}^{\psi} * \mathrm{~A}^{\phi-1}$

and the population growth equation becomes:

(5a) $\frac{\dot{P}}{P}=\frac{g}{1-a} P^{\psi+(1-\alpha)(\phi-1)} \bar{y}^{\phi-1}$

For the empirical regularities observed in Figure 1 to be consistent with this equation, the exponent on $\mathrm{P}$ must be roughly equal to 1 . Given that $\phi$, the exponent of $\mathrm{A}$, is smaller or equal to one, with $\alpha$ being approximately $2 / 3, \psi$ must be greater than 1 , thus suggesting that the increases in research activity afforded by higher population outweigh the duplication effects.

While Kremer motivates this extension as effects of higher population on research activities, his description of these effects, better intellectual contact and specialization and the development of cities, are really effects of population density, not primarily related to absolute population size. Also, the arguments of Kuznets (1960), Agion and Howitt (1992), and Grossman and Helpman (1991) as well as Becker et al. (1999) relate primarily to the effects of population density on technological 
change through its effect on more intensive intellectual contact, urbanization, exchange, and specialization, and through its effect on market size.

Consequently, the next section introduces population density into this extended version of the model. It is intended to present a more plausible version, showing that not only population size, but also population density matters for technological progress. This extension does add to the complexity of the model, but generates interesting new insights into the process of technological change and better explains the data.

\section{Population density and technological change}

The process of endogenous technological change, until now represented by equation (3a), may also be influenced by population density. For instance, a country with a large population may not possess a higher growth rate of technology than a country with a medium sized population, because the population density in the second country is higher. This may be true because the need to invent new technologies from a Boserupian (1981) point of view will be higher in the second country, compensating for the disadvantage of having less inventors in absolute terms. The speed of communication, the diffusion of knowledge, and division of labor could also be higher in the second country, which could lead to a faster pace of technological progress than in the more populous country, following the insights from Kuznets (1960), Becker et al. (1999) and Gallup and Sachs $(1998)^{6}$; or higher population density increases the effective market size and thus raises the returns to innovation. This is not only theoretically plausible but supported empirically by cross-country growth research (e.g. Gallup and Sachs, 1998; Bloom at al. 1999; Nestmann, 2000). To see this formally, this idea will now be incorporated in the framework of Kremer's generalized model.

In this version, the land variable $\mathrm{T}$ will not be normalized to one in the production function. The production function from (1) is reproduced below.

(1) $\mathrm{Y}=\mathrm{A} * \mathrm{P}^{\alpha} \mathrm{T}^{1-\alpha}$

After dividing (1) by $\mathrm{P}$ and rearranging terms, we can identify the per capita production function (1b), which depends on population density (P/T).

$$
\text { (1b) } \mathrm{y}=\mathrm{A} *\left(\frac{\mathrm{P}}{\mathrm{T}}\right)^{\alpha-1}
$$

\footnotetext{
${ }^{5}$ This is a very general formulation that would accommodate a variety of views on technological change including Barro and Sala-i-Martin (1992), Jones (1992, 1995), Aghion and Howitt (1991), among others.
} 
This function can be interpreted as follows: The more people $(\mathrm{P})$ work on a fixed land area $(\mathrm{T})$, the lower will be the marginal productivity per head; conversely, the larger the land area $(\mathrm{T})$, the higher is a person's marginal product. . As in Kremer's model, it is also assumed here that population adjusts instantaneously to economic conditions. Thus the equilibrium population density can be expressed as:

$$
\text { (2b) } \frac{\mathrm{P}}{\mathrm{T}}=\left(\frac{\overline{\mathrm{y}}}{\mathrm{A}}\right)^{\frac{1}{\alpha-1}}
$$

In this new version of the model, the growth rate of technology $(\dot{A} / A)$ depends on research productivity per person, population size, the level of technology, and on population density. The research productivity per person $(\mathrm{g})$ is multiplied by $\mathrm{P}$ to compute total research output in the economy. The level of technology (A) affects the growth rate non-linearly, as Jones $(1992,1995)$ proposed. The variable $\mathrm{d}$ stands for population density, defined as population $(\mathrm{P})$ divided by land $\operatorname{area}(\mathrm{T})$.

$$
\text { (3b) } \frac{\dot{\mathrm{A}}}{\mathrm{A}}=\mathrm{g} * \mathrm{P} * \mathrm{~d}^{\beta} * \mathrm{~A}^{\phi-1}
$$

The functional form of equation (3b) captures that not only population size but also population density influences the growth rate of technology. ${ }^{7}$ The magnitude of the exponent $\beta$ will be determined with help of equation (5b).

In the next step we compute the population growth rate. The growth rate of the land area $T$ is equal to zero, as land area is fixed over time. ${ }^{8}$ From the last section we know how to compute the growth rate of population out of (2) or (2b), respectively. Equation (4b) is therefore equal to equation (4) from Kremer's simple version.

\footnotetext{
${ }^{6}$ Gallup and Sachs (1998) differentiate between the effects of population density in the hinterland and in coastal regions. The beneficial effects of population density only are supposed to appear in coastal regions.

${ }^{7}$ In our model we only consider technological progress and do not make allowances for technological regress due to either 'depreciation' of technical knowledge and/or falling populations. Aiyar and Dalgaard (2001) provide a model, in which imperfect knowledge transfers from one generation to the next may result in technological regress. In particular, the model describes how technological levels might decrease due to a fall in population density which might explain technological regress in some historical and geographic circumstances. These insights supplement our own analysis here, which we believe is more relevant at the global level examined here. For a related discussion, see Kremer (1993)

${ }^{8}$ The global land area has indeed not changed drastically over the past 1 million years and in this simple formulation of a global relationship, this assumption may be reasonable. See also discussion below about population and technological change in geographically separate regions which examines this issue at a more disaggregated level.
} 


$$
\frac{\dot{\mathrm{P}}}{\mathrm{P}}=\frac{1}{1-\alpha} \frac{\dot{\mathrm{A}}}{\mathrm{A}}
$$

Multiplying (4b) by T/T and substituting for $\dot{A} / A$ leads to the final equation (5b):

$$
\frac{\dot{P}}{P}=\left(\frac{T g \bar{y}^{\phi-1}}{(1-\alpha)}\right)\left(\frac{P}{T}\right)^{1+\beta+(1-\alpha)(\phi-1)}
$$

Kremer assumes that the share of labor $(\alpha)$ in the production process is roughly two thirds; he also follows Jones (1995) in assuming that $\phi<1$. Over most of human history, the growth rate of population was proportional to its size. Because of this observation, the exponent of $\mathrm{P} / \mathrm{T}$ is supposed to be roughly equal or slightly less than one. ${ }^{9}$ If it is true that:

$$
1+\beta+(1-\alpha)(\phi-1) \leq 1
$$

then, substituting the values for $\alpha$ and $\phi$ leads to the prediction that $\beta$ is between zero and one. This can be interpreted as follows: The influence of population density on technological change is positive but decreasing over time. The transfer of knowledge is faster, the higher population density becomes, but note that the speed of this transfer is not unlimited. Although the absolute value still increases over time, the marginal increase of the growth rate in technological diffusion declines. For a single country, its own level of technology may, at lower levels of population density, also be more influenced by population density than at higher levels.

But population density does not only represent the diffusion of technology but also the need and the ability to use a new technology. Assuming that a certain population density is necessary to generate the demand for technological change and generate the requisite local market, this population density spurs technological change particularly for countries with low levels of technology. Similarly, higher density increases returns to investments in public goods such as power or other infrastructure (see Simon, 1977; Frederiksen, 1981), and these investments in turn could also work as catalysts for the rate of technological change. Once the infrastructure has been built, the influence of population density is concentrated only on the diffusion process and less on the demand factors and the basic infrastructure necessary for efficient technological spillovers, which could account for the falling marginal returns from population density. Moreover, if population density becomes too high, the costs of selecting the right information increases and this could lower the benefits of a faster

\footnotetext{
${ }^{9}$ If it were slightly less than one, it may also account for the fall in population growth after 1960 in Figure 1. But see also below.
} 
knowledge transfer. The inference from the empirical evidence, which lead to a positive but declining influence of population density on the growth rate of technology is consistent with these arguments.

This version of the model can then be extended, as was Kremer's, to no longer assume instantaneous adjustment of population to income levels. If now population adjusts only slowly to rising incomes, it is possible for per capita incomes to increase, and these rising per-capita incomes in turn reduce population growth (e.g. Becker 1981, Willis, 1973) and thus may generate the turning point observed in Figure 1. In this version with population density, per capita income growth would be faster than in the Kremer version and also in line with observed income growth over the past century.

Thus the inclusion of population density more plausibly explains the empirical findings on population and population growth through the above argument on the positive, but declining impact of population density on technological change. This explanation appears more plausible than Kremer's original version which only turns on population levels and not on its density.

\section{Empirical Tests and their Interpretation}

Since global population density has changed, one for one, with global population (as the global land area has been roughly fixed over the past few millenia), the empirical tests of Kremer's hypothesis apply to this formulation of the model as well and need not be replicated here but will only be briefly summarized. ${ }^{10}$ Kremer shows that the linear relationship between population levels and its growth rate shows up econometrically and is robust to corrections for heteroscedasticity, different data sources for world population, and changes in time periods under investigation. It not only holds for the entire world, but also when specific regions between which there was only limited exchange of technologies (e.g. Europe, China, and India) are considered separately. In our interpretation, it was the rising population and the rising population density which ensured the acceleration of technological progress in the world, and the three regions, which then in turn relaxed the Malthusian constraint and allowed population levels to grow further. ${ }^{11}$

\footnotetext{
${ }^{10}$ For the aggregate analysis undertaken here, the assumption of a fixed land area appears reasonable. If one were to examine technological change at a more disaggregated level, settlement patterns that shift the inhabited land areas as well as alter local population densities would be important to account for actual trends in technological change over space and time. See also analysis of geographically separate regions below.

${ }^{11}$ For details, see Kremer (1993) which also includes a careful discussion of the data sources and potential biases.
} 
For the second part of Kremer's empirical tests, however, our model has a different interpretation. In that part, Kremer examines population and population density of five technologically separate regions around 1500 to test whether those regions with the lowest population indeed had the lowest population growth. He shows that there appears to be a close correlation between population and technological levels in those five regions which separated around 10000 B.C. The regions with the lowest population density, Tasmania and Flinder's Island (where population appears to have died out about 6000 B.C), also had the lowest technological levels, while the much more populous Old World was the place with the highest level of technologies in 1500 . He also claims that the regions with the lowest population in 1500 must have had the lowest population growth up until 1500 since their population density in 1500 was lowest. Table VII from his paper has been complemented with data on population and population density for AD1 and AD1000 and is shown below as Table 1. His second claim hinges on the assumption that all five regions started out at the time of their separation (around 10,000 BC) with roughly the same population density. Only with this assumption can the population density in 1500 say anything about population growth prior to that.

Table 1: Population and Population Density in Technologically Separated Regions

\begin{tabular}{|l|ccc|c|ccc|}
\hline & Population & & & \multicolumn{3}{|c|}{ Population Density } \\
& AD1 & 1000 & 1500 & Area & AD1 & 1000 & 1500 \\
\hline Old World & 162.5 & 254 & 407 & 83.98 & 1.94 & 3.04 & 4.85 \\
Americas & 4.5 & 9 & 14 & 38.43 & 0.11 & 0.23 & 0.36 \\
Australia & 0.2 & 0.2 & 0.2 & 7.69 & 0.03 & 0.03 & 0.026 \\
Tasmania & & & $0.0012-0.005$ & 0.068 & & & $0.018-0.074$ \\
Flinders Island & & & 0 & 0.0068 & & & 0 \\
\hline
\end{tabular}

Sub-Saharan Africa is included in the old world (which is otherwise comprised of Eurasia), since there was some contact across the Sahara. There are a wide range of population estimates for the Americas and Australia at the time of European arrival, and McEvedy and Jones's are at the low end. However, higher estimates would not affect the rank ordering. Estimates for Tasmania are based on the Encyclopaedia Brittanica. There are no reliable population estimates for Tasmania prior to 1500.

Source: Kremer (1993), McEvedy and Jones (1978).

Adding further data from McEvedy and Jones, which were used by Kremer in Table 1, question the empirical validity of this assumption. Instead it appears that the Old World in $1 \mathrm{AD}$, and also in $1000 \mathrm{AD}$ had considerably higher population densities than the Americas and Australia. 
While we do not know whether this was true already at the time of separation, the differences are so large that it is more than likely to have been the case. ${ }^{12}$

Using our model with population density, one can reinterpret the findings from Table 1 more convincingly. In particular, we no longer need to assume equal population densities at the time of separation but can replace that with the more realistic assumption that population density of these separate regions differed already at the time of separation, with the Old World already having the highest population density, and the Americas, Australia, Tasmania, and Flinder's Island each having smaller population densities. As a result, it was the low initial population density (in addition to low population) that ensured that the latter regions remained technologically backward, while the more densely settled Old World developed progressively better technologies. The considerable differences in population growth between AD1 and AD1000 and AD1500 between the regions would support this conjecture. Moreover, our model would clearly predict that the combination of higher population and higher population density in the Old World ensured that most technological progress the world has seen since 1500 originated in that region (see also Boserup, 1981).

Our model can be further supported by looking at more disaggregated data on population, population density and GDP (as a proxy for the level of technological development). Appendix Table 1 presents data on population and population density for several Western European countries separately and aggregated data for several regions such as Eastern Europe, the former USSR, Western Offshoots, Latin America and Africa, both in AD0 and AD1000. The Table also shows data on PPP-adjusted real per capita GDP in AD1500 from Maddison (2001). These new data confirm that the regions where technological progress took off around 1500, especially Italy and central Europe had significantly higher population densities than e.g. the United States, the former USSR or Africa, all being regions that can be considered technologically backward at that time. India and China have relatively high population densities and were countries with recurrent episodes of high technological progress, although both were not particularly wealthy in 1500 .

In fact, Figure 2 and the regressions in Table 2 demonstrate a close correspondence between population density in AD0 (or in AD1000) and per capita GDP in 1500, suggesting that more densely populated regions experienced greater technological progress after 1000, when (according

\footnotetext{
${ }^{12}$ Using alternative data from Clark (1968) or from Durand (1977) supports the contention of vastly different population densities between the Old World and the Americas and Australia up until the earliest times. This conclusion would be strengthened if one excluded Africa South of the Sahara from the Old World. Clark's and Durand's data have considerably higher numbers for the old world at AD1 and consequently lower population growth after that.
} 
to Maddison (2001)) the divergence in per capita incomes between countries began to emerge. The strong and highly significant influence of population density on subsequent technological change is robust to whether we use density in $\mathrm{AD} 0$ or $\mathrm{AD} 1000$, and whether we include or exclude some outliers. $^{13}$

At the same time, we observe from Figure 3 that the correlation between population size in $\mathrm{AD0}$ (or AD1000) and per capita GDP in AD1500 is close to zero. This supports our contention that population size alone was not primarily responsible for technological change, while population density clearly played an important role; in fact, the data seem to suggest it played a more important role than population size.

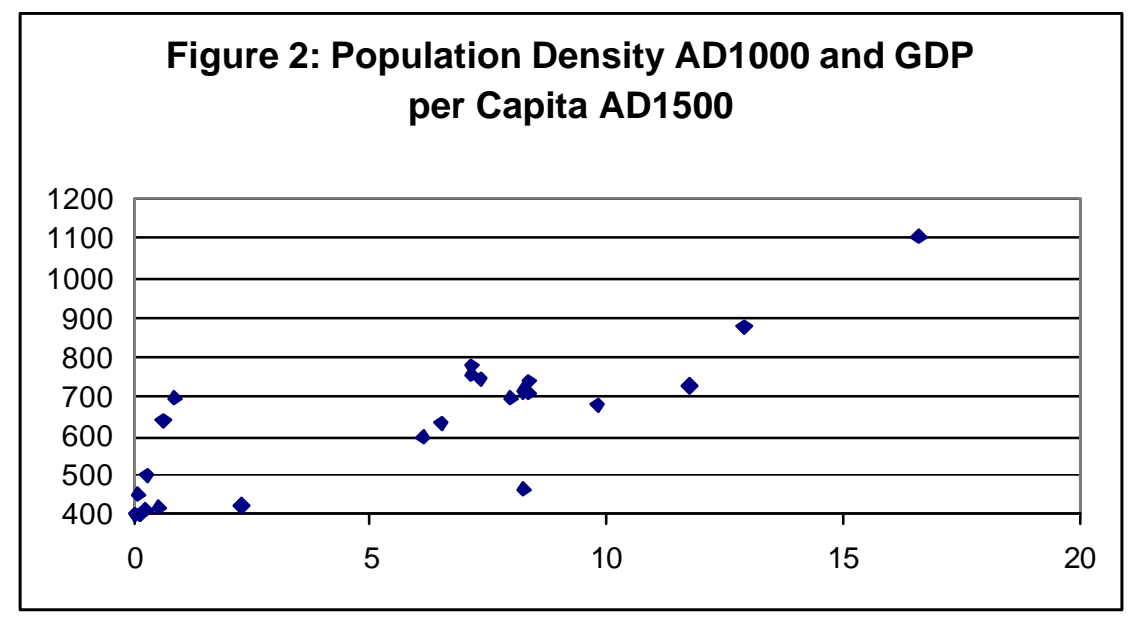

Source: McEvedy and Jones (1978), Maddison (2001), and World Bank (2002). Note that two outliers (India and Japan) are excluded. As shown in the Table 2, they affect the correlation only marginally.

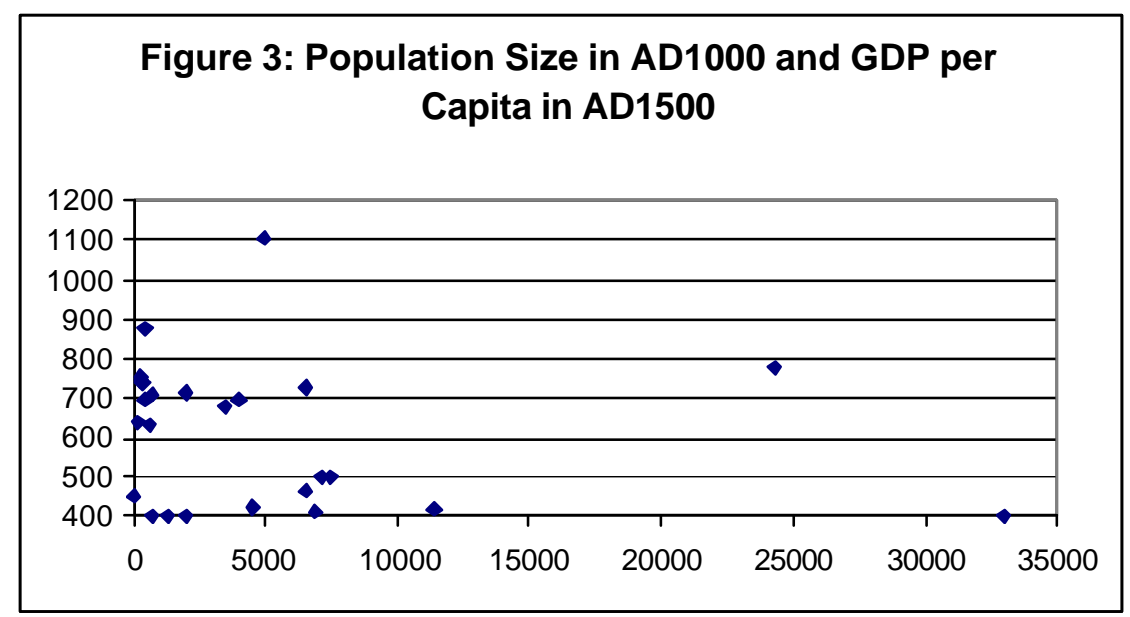

Source: McEvedy and Jones (1978); Maddison (2001), and World Bank (2002). Note that two outliers (India and China) are excluded. As shown in the Table 2, they affect the correlation only marginally.

\footnotetext{
${ }^{13}$ When we remove outliers (Italy and India in AD0 and India and Japan in AD1000), the influence of population density becomes much stronger and explains a surprisingly large share of the variation in per capita incomes in 1500. Arguably it is useful to remove at least Italy and India from the regressions as they were experiencing a
} 
Table 2: Population, Population Density, and Per Capita GDP in 1500

\begin{tabular}{|l|l|l|l|l|l|l|}
\hline & $(1)$ & $(1) \#$ & $(2)$ & $(2) \#$ & $(3)$ & $(4)$ \\
\hline Constant & $\begin{array}{l}512.6^{* * * *} \\
(36.1)\end{array}$ & $\begin{array}{l}473.8^{* * *} \\
(14.2)\end{array}$ & $\begin{array}{l}511.4^{* * *} \\
(12.0)\end{array}$ & $\begin{array}{l}443.3^{* * *} \\
(14.9)\end{array}$ & $\begin{array}{l}610.3^{* * *} \\
(16.0)\end{array}$ & $\begin{array}{l}619.0 * * * \\
(15.8)\end{array}$ \\
\hline $\begin{array}{l}\text { Pop. Dens. } \\
\text { AD0 }\end{array}$ & $\begin{array}{l}17.8^{* * *} \\
(4.0)\end{array}$ & $\begin{array}{l}29.8^{* * *} \\
(4.6)\end{array}$ & & & & \\
\hline $\begin{array}{l}\text { Pop. Dens. } \\
1000\end{array}$ & & & $\begin{array}{l}14.7 * * \\
(3.1)\end{array}$ & $\begin{array}{l}32.0^{* * *} \\
(7.6)\end{array}$ & & \\
\hline Pop. AD0 & & & & & $\begin{array}{l}-0.0004 \\
(0.2)\end{array}$ & \\
\hline $\begin{array}{l}\text { Pop. } \\
\text { AD1000 }\end{array}$ & & & & & & -0.001 \\
\hline Adj. R-Sq. & 0.36 & 0.46 & 0.25 & 0.70 & -0.04 & -0.02 \\
\hline $\mathrm{N}$ & 27 & 25 & 27 & 25 & 27 & 27 \\
\hline
\end{tabular}

Note: Dependent variable is PPP adjusted per capita GDP for 1500. Regressions with \# exclude outliers. Dropping outliers from regressions 3 and 4 did not change the results. Absolute t-statistics in parentheses. $* * *$ refers to $99.9 \%, * *$ to $99 \%$, and * to $95 \%$ significance.

Source: Observations based on Maddison (2001).

\section{Conclusion}

This note incorporates population density as an additional determinant of technological change within the framework of Kremer's (1993) model. While population increases the number of potential suppliers of new technology, population density generates the linkages, the infrastructure, the demand, and the effective market size for technological innovations. The model and the available data suggest a concave relationship between population density and technological change. This model is able to better explain the empirical relationship between population, population density, and population growth, and can provide a better account of the differences in technological levels between geographically separate regions than the account provided by Kremer (1993).

The revised model not only explains the historical record in a more plausible fashion, but also has interesting implications for understanding differences in growth and development among different parts of the developing world. For example, a conclusion of this model is that Africa's development challenge is particularly difficult given its combination of relatively low population levels at the beginning of modern economic growth combined with a very low population density both of which hamper technological change and diffusion. The rapid population growth Africa is currently experiencing might in time reduce this burden and ease technological change and diffusion, but only at 
high current costs that such high population growth entails. ${ }^{14}$ Conversely, economic development in Asia was greatly aided by high populations and large population densities that facilitated technological change and diffusion. Regarding policy implications, our findings suggest that effort should be directed at overcoming the limits and constraints imposed by low population density. Policies aimed at improving the physical and technological infrastructure would clearly be important in this regard.

\footnotetext{
${ }^{14}$ For a related discussion, see Gallup and Sachs (1998). Low population density might have other negative effects such as greater ethnic divisions which has also been found to reduce economic growth (Easterly and Levine, 1997). At the same time, it is not clear whether high population densities are still as essential as they used to be given that modern transport and communication technologies offer, if available, greater technological diffusion even without high population densities. But also here, Africa seriously lags behind.
} 


\begin{tabular}{|c|c|c|c|c|c|c|}
\hline Country & $\begin{array}{l}\text { Surface Area } \\
\left(1000 \mathrm{~km}^{2}\right)\end{array}$ & $\begin{array}{c}\text { Population (Tsd.) } \\
\text { in AD0 }\end{array}$ & $\begin{array}{l}\text { Population (Tsd.) } \\
\text { in AD1000 }\end{array}$ & $\begin{array}{c}\text { Population density } \\
\text { in AD0 }\end{array}$ & $\begin{array}{l}\text { Population density } \\
\text { in AD1000 }\end{array}$ & $\begin{array}{c}\text { GDP per capita } \\
\text { in AD1500 }\end{array}$ \\
\hline Austria & 84 & 500 & 700 & 5.95 & 8.33 & 707 \\
\hline Belgium & 31 & 300 & 400 & 9.68 & 12.90 & 875 \\
\hline Denmark & 43 & 180 & 360 & 4.19 & 8.37 & 738 \\
\hline Finland & 338 & 20 & 40 & 0.06 & 0.11 & 453 \\
\hline France & 552 & 5000 & 6500 & 9.06 & 11.77 & 727 \\
\hline Germany & 357 & 3000 & 3500 & 8.40 & 9.80 & 676 \\
\hline Italy & 301 & 7000 & 5000 & 23.26 & 16.61 & 1100 \\
\hline Netherlands & 42 & 200 & 300 & 4.76 & 7.14 & 754 \\
\hline Norway & 324 & 100 & 200 & 0.31 & 0.61 & 640 \\
\hline Sweden & 450 & 200 & 400 & 0.44 & 0.88 & 695 \\
\hline Switzerland & 41 & 300 & 300 & 7.32 & 7.31 & 742 \\
\hline United Kingdom & 243 & 800 & 2000 & 3.29 & 8.23 & 714 \\
\hline Portugal & 92 & 500 & 600 & 5.43 & 6.52 & 632 \\
\hline Spain & 506 & 4500 & 4000 & 8.89 & 7.95 & 698 \\
\hline Western Europe* & 3404 & 22600 & 24300 & 6.64 & 7.14 & 774 \\
\hline Eastern Europe $* *$ & 786 & 4750 & 6500 & 6.04 & 8.27 & 462 \\
\hline Former USSR $* * *$ & 24971 & 3900 & 7100 & 0.16 & 0.28 & 500 \\
\hline United States & 9629 & 680 & 1300 & 0.07 & 0.13 & 400 \\
\hline Other Western Offshoots $* * * *$ & 17983 & 490 & 660 & 0.03 & 0.03 & 400 \\
\hline Total Western Offshoots & 27612 & 1170 & 1960 & 0.04 & 0.07 & 400 \\
\hline Mexico & 1958 & 2200 & 4500 & 1.12 & 2.29 & 425 \\
\hline Other Latin America $* * * * *$ & 18501 & 3400 & 6900 & 0.18 & 0.25 & 410 \\
\hline Total Latin America & 20459 & 5600 & 11400 & 0.27 & 0.55 & 416 \\
\hline Japan & 378 & 3000 & 7500 & 7.94 & 19.84 & 500 \\
\hline China & 9598 & 59600 & 59000 & 6.21 & 6.14 & 600 \\
\hline India & 3287 & 75000 & 75000 & 22.82 & 22.81 & 550 \\
\hline Africa & 28821 & 16500 & 33000 & 0.57 & 1.14 & 400 \\
\hline World & 110200 & 230820 & 268273 & 2.09 & 2.43 & 565 \\
\hline
\end{tabular}

Notes:*Austria, Belgium, Denmark, Finland, France, Germany, Italy, Netherlands, Norway, Sweden, Switzerland, United Kingdom, Portugal, and Spain. **Comprising of Albania, Bulgaria, Czechoslovakia, Hungary, Poland, Romania, and former Yugoslavia. *** Armenia, Azerbaijan, Belarus, Estonia, Georgia, Kazakhstan, Kyrgyzstan, Latvia, Lithuania, Moldova, Russian Federation, Tajikistan, Turkmenistan, Ukraine, Uzbekistan. **** Australia, New Zealand, Canada. ***** Argentina, Brazil, Chile, Colombia, Peru, Uruguay, Venezuela, Bolivia, Costa Rica, Cuba, Dominican Republic, Ecuador, El Salvador, Guatemala, Haiti, Honduras, Jamaica, Nicaragua, Panama, Paraguay, Puerto Rico, Trinidad \& Tobago.

Sources: Surface Area was taken from the World Development Indicators 2002. Population figures as well as GDP data was taken from Maddison (2001). Population density was calculated by dividing total population by surface area. 


\section{References}

Aghion, P. and P. Howitt (1992), 'A Model of Growth through Creative Destruction', Econometrica 60: 323-52.

Aiyar S. and C.-J. Dalgaard (2001), 'Why does technology sometimes regress?', Working paper, University of Kopenhagen.

Barro, R. and X. Sala-i-Martin (1995), Economic Growth. New York: McGraw-Hill.

Becker, G. (1981), A Treatise on the Family. Cambridge: Harvard University Press.

-----, E. Glaeser, and K. Murphy (1999), Population and Economic Growth American Economic Review 89 No. 2: 145-149.

Bloom, D.E. Canning, D. and P.N. Malaney (1999), 'Demographic Change and Economic Growth in Asia'. CID Working Paper No. 15, Center for International Development, Harvard University.

Boserup, E. (1981), Population and Technological change: A study of long term trends, Chicago: University of Chicago Press.

Clark, C. (1968), Population Growth and Land Use. London: Macmillan.

Durand, J. (1977), 'Historical Estimates of World Population: An Evaluation', Population and Development Review 3: 253-96.

Easterly, W and R. Levine (1997), 'Africa's Growth Tragedy: Policies and Ethnic Divisions', Quarterly Journal of Economics 112: 1203-50.

Frederiksen, P. (1981), 'Further Evidence on the relationship between population density and infrastructure: the Philippines and electrification', Economic Development and cultural Change: $749-758$.

Gallup, J. and J. Sachs. (1998), 'Geography and Economic Development'， In Stiglitz, J. (ed.). The 1998 Annual Bank Conference on Development Economics, Washington DC: The World Bank.

Galor, O., Weil, D. (1999), 'From Malthusian stagnation to modern growth', American Economic Review 89(2): 150-154.

Grossman, E. M. and E. Helpman (1991), Innovation and Growth in the Global Economy, Cambridge: MIT Press.

Jones, C. (1992), 'R\&D Based Models of Economic Growth’, unpublished, MIT. 
Jones, C. (1995), 'R\&D Based Models of Economic Growth', Journal of Political Economy 103: 759-784.

Kremer, M. (1993), 'Population growth and technological change one million b. C. to 1990', Quarterly Journal of Economics 108: 681-716.

Kuznets, S. (1960), 'Population Change and Aggregate Output', Kuznets, S: Demographic and Economic Change in Developed Countries. Princeton, NY: Princeton University Press.

Maddison, A. (2001), The World Economy: A Milleniam Perspective. Paris: OECD.

McEvedy, C. and R. Jones (1978), Atlas of World population History. London: Penguin.

Nestmann, T. (2000), Der Einfluss von Bevölkerungsdichte auf das Wirtschaftswachstum: Theorie und Empirie. MA Thesis, Department of Economics, University of Munich.

Romer, P. (1990), 'Endogenous Technological Change', Journal of Political Economy 98: 71102.

Simon, J. (1977), The Economics of Population Growth, Princeton, NY: Princeton University Press.

United Nations (1998), Demographic Yearbook 1996. New York: United Nations.

Willis, R. (1982), 'The Direction of Intergenerational Transfers and Demographic Transition', Population and Development Review 8 (supplement): 207-234.

World Bank. (2002), World Development Indicators. CD-Rom. 


\section{CESifo Working Paper Series}

(for full list see www.cesifo.de)

1144 Sascha O. Becker, Samuel Bentolila, Ana Fernandes, and Andrea Ichino, Job Insecurity and Children's Emancipation, March 2004

1145 Pascalis Raimondos-Møller and Alan D. Woodland, Non-Preferential Trading Clubs, March 2004

1146 Robert Fenge and Matthias Wrede, EU Regional Policy: Vertical Fiscal Externalities and Matching Grants, March 2004

1147 Chi-Yung Ng and John Whalley, Geographical Extension of Free Trade Zones as Trade Liberalization: A Numerical Simulation Approach, March 2004

1148 Marc-Andreas Muendler, Trade, Technology, and Productivity: A Study of Brazilian Manufacturers, 1986-1998, March 2004

1149 Eugene Beaulieu, Vivek H. Dehejia, and Hazrat-Omar Zakhilwal, International Trade, Labour Turnover, and the Wage Premium: Testing the Bhagwati-Dehejia Hypothesis for Canada, March 2004

1150 Giorgio Brunello and Francesca Gambarotto, Agglomeration Effects on EmployerProvided Training: Evidence from the UK, March 2004

1151 S. Brock Blomberg, Gregory D. Hess, and Athanasios Orphanides, The Macroeconomic Consequences of Terrorism, March 2004

1152 Bodo Sturm and Joachim Weimann, Unilateral Emissions Abatement: An Experiment, March 2004

1153 Wolfgang Ochel, Welfare-to-Work Experiences with Specific Work-First Programmes in Selected Countries, March 2004

1154 Jan K. Brueckner and Eric Pels, European Airline Mergers, Alliance Consolidation, and Consumer Welfare, March 2004

1155 Aaron Tornell, Frank Westermann, and Lorenza Martínez, NAFTA and Mexico's Economic Performance, March 2004

1156 George Economides, Sarantis Kalyvitis, and Apostolis Philippopoulos, Do Foreign Aid Transfers Distort Incentives and Hurt Growth? Theory and Evidence from 75 Aidrecipient Countries, March 2004

1157 Robert Fenge and Volker Meier, Are Family Allowances and Fertility-related pensions Siamese Twins?, March 2004 
1158 Bruno S. Frey, Simon Luechinger, and Alois Stutzer, Valuing Public Goods: The Life Satisfation Approach, March 2004

1159 Jerome L. Stein and Guay C. Lim, Asian Crises: Theory, Evidence, Warning-Signals, March 2004

1160 Romain Ranciere, Aaron Tornell, and Frank Westermann, Crises and Growth: A ReEvaluation, March 2004

1161 Assaf Razin and Efraim Sadka, Transparency, Specialization and FDI, March 2004

1162 Ludger Woessmann, How Equal Are Educational Opportunities? Family Background and Student Achievement in Europe and the United States, March 2004

1163 B.M.S. van Praag and Barbara E. Baarsma, Using Happiness Surveys to Value Intangibles: The Case of Airport Noise, March 2004

1164 Aaron Tornell, Frank Westermann, and Lorenza Martínez, The Positive Link Between Financial Liberalization, Growth, and Crises, March 2004

1165 Helge Berger and Carsten Hefeker, One Country, One Vote? Labor Market Structure and Voting Rights in the ECB, March 2004

1166 Clemens Fuest and Martin Kolmar, A Theory of User-Fee Competition, March 2004

1167 Friedrich Schneider and Robert Klinglmair, Shadow Economies around the World: What Do We Know?, April 2004

1168 Horst Raff and Nicolas Schmitt, Exclusive Dealing and Common Agency in International Markets, April 2004

1169 M. Hashem Pesaran and Allan Timmermann, Real Time Econometrics, April 2004

1170 Sean D. Barrett, Privatisation in Ireland, April 2004

1171 V. Anton Muscatelli, Patrizio Tirelli and Carmine Trecroci, Can Fiscal Policy Help Macroeconomic Stabilisation? Evidence from a New Keynesian Model with Liquidity Constraints, April 2004

1172 Bernd Huber and Marco Runkel, Tax Competition, Excludable Public Goods and User Charges, April 2004

1173 John McMillan and Pablo Zoido, How to Subvert Democracy: Montesinos in Peru, April 2004

1174 Theo Eicher and Jong Woo Kang, Trade, Foreign Direct Investment or Acquisition: Optimal Entry Modes for Multinationals, April 2004

1175 Chang Woon Nam and Doina Maria Radulescu, Types of Tax Concessions for Attracting Foreign Direct Investment in Free Economic Zones, April 2004 
1176 M. Hashem Pesaran and Andreas Pick, Econometric Issues in the Analysis of Contagion, April 2004

1177 Steinar Holden and Fredrik Wulfsberg, Downward Nominal Wage Rigidity in Europe, April 2004

1178 Stefan Lachenmaier and Ludger Woessmann, Does Innovation Cause Exports? Evidence from Exogenous Innovation Impulses and Obstacles, April 2004

1179 Thiess Buettner and Johannes Rincke, Labor Market Effects of Economic Integration The Impact of Re-Unification in German Border Regions, April 2004

1180 Marko Koethenbuerger, Leviathans, Federal Transfers, and the Cartelization Hypothesis, April 2004

1181 Michael Hoel, Tor Iversen, Tore Nilssen, and Jon Vislie, Genetic Testing and Repulsion from Chance, April 2004

1182 Paul De Grauwe and Gunther Schnabl, Exchange Rate Regimes and Macroeconomic Stability in Central and Eastern Europe, April 2004

1183 Arjan M. Lejour and Ruud A. de Mooij, Turkish Delight - Does Turkey's accession to the EU bring economic benefits?, May 2004

1184 Anzelika Zaiceva, Implications of EU Accession for International Migration: An Assessment of Potential Migration Pressure, May 2004

1185 Udo Kreickemeier, Fair Wages and Human Capital Accumulation in a Global Economy, May 2004

1186 Jean-Pierre Ponssard, Rent Dissipation in Repeated Entry Games: Some New Results, May 2004

1187 Pablo Arocena, Privatisation Policy in Spain: Stuck Between Liberalisation and the Protection of Nationals' Interests, May 2004

1188 Günter Knieps, Privatisation of Network Industries in Germany: A Disaggregated Approach, May 2004

1189 Robert J. Gary-Bobo and Alain Trannoy, Efficient Tuition Fees, Examinations, and Subsidies, May 2004

1190 Saku Aura and Gregory D. Hess, What's in a Name?, May 2004

1191 Sjur Didrik Flåm and Yuri Ermoliev, Investment Uncertainty, and Production Games, May 2004

1192 Yin-Wong Cheung and Jude Yuen, The Suitability of a Greater China Currency Union, May 2004 
1193 Inés Macho-Stadler and David Pérez-Castrillo, Optimal Enforcement Policy and Firms' Emissions and Compliance with Environmental Taxes, May 2004

1194 Paul De Grauwe and Marianna Grimaldi, Bubbles and Crashes in a Behavioural Finance Model, May 2004

1195 Michel Berne and Gérard Pogorel, Privatization Experiences in France, May 2004

1196 Andrea Galeotti and José Luis Moraga-González, A Model of Strategic Targeted Advertising, May 2004

1197 Hans Gersbach and Hans Haller, When Inefficiency Begets Efficiency, May 2004

1198 Saku Aura, Estate and Capital Gains Taxation: Efficiency and Political Economy Consideration, May 2004

1199 Sandra Waller and Jakob de Haan, Credibility and Transparency of Central Banks: New Results Based on Ifo's World Economicy Survey, May 2004

1200 Henk C. Kranendonk, Jan Bonenkamp, and Johan P. Verbruggen, A Leading Indicator for the Dutch Economy - Methodological and Empirical Revision of the CPB System, May 2004

1201 Michael Ehrmann, Firm Size and Monetary Policy Transmission - Evidence from German Business Survey Data, May 2004

1202 Thomas A. Knetsch, Evaluating the German Inventory Cycle - Using Data from the Ifo Business Survey, May 2004

1203 Stefan Mittnik and Peter Zadrozny, Forecasting Quarterly German GDP at Monthly Intervals Using Monthly IFO Business Conditions Data, May 2004

1204 Elmer Sterken, The Role of the IFO Business Climate Indicator and Asset Prices in German Monetary Policy, May 2004

1205 Jan Jacobs and Jan-Egbert Sturm, Do Ifo Indicators Help Explain Revisions in German Industrial Production?, May 2004

1206 Ulrich Woitek, Real Wages and Business Cycle Asymmetries, May 2004

1207 Burkhard Heer and Alfred Maußner, Computation of Business Cycle Models. A Comparison of Numerical Methods, June 2004

1208 Costas Hadjiyiannis, Panos Hatzipanayotou, and Michael S. Michael, Pollution and Capital Tax Competition within a Regional Block, June 2004

1209 Stephan Klasen and Thorsten Nestmann, Population, Population Density, and Technological Change, June 2004 